acologists but also clinicians, chemists, biochemists, physicists, bacteriologists, pathologists and other biologists, working in both university and industrial laboratories, have contributed to these advances, but their work is scattered throughout numerous journals. The new journal will bring together work, in all these fields, which is concerned with the effects of chemical substances on animals, living tissues and their chemical systems. It will publish original work in all branches of pharmacology and experimental chemotherapy, including the biochemical and pathological aspects of this subject. Provision will also be made for shorter communications and for brief notes on technique.

The editorial board of the new journal is : Prof. J. H. Gaddum, professor of pharmacology, University of Edinburgh (chairman); Prof. J. H. Burn, professor of pharmacology, University of Oxford ; Dr. F. Hawking, of the research staff of the Medical Research Council; Dr. H. R. Ing, reader in pharmacological chemistry, University of Oxford; Dr. N. Mutch, physician to Guy's Hospital; Dr. C. M. Scott, director of the Pharmacological Laboratories, Imperial Chemical Industries, Ltd. ; Prof. F. R. Winton, professor of pharmacology, University of London; and the editor of the British Medical Journal. Papers intended for publication should be sent to Dr. H. R. Ing, Department of Pharmacology, Oxford. Each volume will consist of four quarterly parts and will cost $25 s$. Subscriptions, payable in advance, should be sent to the British Medical Association, B.M.A. House, Tavistock Square, London, W.C.1.

\section{Organisation of Research in the United States}

Av open letter signed by the members of a committee supporting the Bush Report has been addressed to President Truman on pending legislation for Federal aid to science (Science, 102, 545, 1945). The letter indicates that the committee favours the Magnuson Bill and is opposed to the Kilgore Bill. It believes that the main responsibility for the programme should be placed in the hands of a national science or research board composed of laymen and scientific men appointed by the President solely on the basis of interest in, and capacity to promote, scientific research and education. The committee is emphatically opposed to the subordination of the board to a single director appointed by the President, as is done in the Kilgore Bill. The board should be responsible for the appointment of the chief administrative officer of the foundation and no ex officio members of other Government agencies should serve as active members of the board. The committee does not think that the board should undertake to control or co-ordinate all Government scientific activity, but that, given high standards and sound practice in scientific education and research, the proliferation of interests and activities, together with a high degree of institutional and individual freedom and respon. sibility, is desirable. It is considered that social sciences should be taken care of by a separate body, and the point of view expressed in this letter is endorsed on behalf of the combined executive committees of the Union of American Biological Societies and of the American Biological Society, in a note signed by Prof. Robert Chambers and Prof. J. S. Nicholas, the respective presidents, which indicate that, as biologists, they are keenly interested in realizing the contemplated plans to include the biological sciences in a division of basic science separate from medical research and public welfare.

\section{Visual Education in China}

THE University of Nanking is contributing vitally to educational development in China in its MotionPicture Department, now ten years old. The Department has provided a two-year college course in motion-picture and radio, now to be extended to a full four-year course-a most important step which incidentally has no counterpart in Great Britain. Graduates spread all over China, and some have been sent to study cinematography in the United States. The Department issues a monthly periodical, Film and Radio, containing both technical and general information and illustrations. It has provided an extensive programme of motion-picture and filmstrip shows for war information, general education and instruction. Films from British, American and Canadian sources are used, but an increasing number are produced in China.

The figures are impressive. At Cheng-tu (to which the University evacuated) fortnightly open-air shows averaged audiences of 10,000 with a peak of 29,000 . In 1944 , a total of 826 shows were organised, the aggregate audiences being more than 800,000 . Nearly 6,000 film-strips were shown to more than a million people during the first four months of 1945 . Leading professors are contributing to a production programme of two educational film-strips a month. The film is now part of the communal and university life, and is extensively used by professors and students. Many organisations and war factories in the Cheng-tu area have benefited by the work of the Department. In the University itself, a projection room, dark room and studio are provided for the use of staff and students. It has planned to extend this pioneer work of administration, training and research to five other universities.

\section{Animal Population Research in India}

THE problems of animal population and migration have aroused increasing interest of recent years, and in stressing the need of a central institute in India, Major Roonwal, assistant superintendent of the Zoological Survey, will have the sympathy of most naturalists (Sci. and Culture, 11, 10 ; 1945-46). Attention is directed to similar work in other countries, especially in the United States, with its Fish and Wild Life Service, and the U.S.S.R., where very extensive studies have been made on animal populations, those on mammals and insects being the most extensive. In the U.S.S.R. there is a tendency to seek for causes of fluctuation in climate, and experimental work on the American model is not much in vogue. British research on the subject has been largely centred at the Bureau of Animal Population, Oxford, under the direction of Mr. C. Elton. Its practical applications are of the highest value to agriculture, fisheries and public health. Plagues of insects and mammals, especially rodents, are familiar to agriculturists the world over, and even in normal times their depredations are enormous. Fisheries fluctuate from year to year, and up to now little is known of the factors which govern the natural periodic rhythms of fish populations.

Finally, mammals play an important part in the transmission of various diseases in India, one of the best-known examples being the relationship between rats and bubonic plague, and although there is some indication of short population rhythms in India, there have been no extensive studies such as those being carried on in the U.S.S.R. on the fluctuations of mouse-like rodents associated with plague. The 
complexity of these problems demands the services of a team of workers, extending over many years, and can only be carried out with the aid of a central organisation, which should serve as a centre both for receiving questions and transmitting information. It is suggested that there should be established forthwith in India a central institute of animal population and migration, staffed by competent zoologists whose main function would be the study of vertebrate populations and migrations from all points of view.

\section{Length of the Small Intestine}

Prow. J. B. Creland, of the University of Adelaide, writes: "In Nature of March 17, 1945 (p. 327), the maximum length of the small intestine quoted is $28 \mathrm{ft} .4 \mathrm{in}$. In the Medical Journal of Australia of September 30,1944 (p. 359), I have given the lengths of the small intestine (not including the duodenum) in a hundred post-mortems at Adelaide. The longest five, all being males, were $30 \mathrm{ft}$., $31 \mathrm{ft}$., $33 \mathrm{ft}$., $35 \mathrm{ft}$., and $37 \mathrm{ft}$. ; the longest in a female subject was $29 \mathrm{ft} . "$

\section{Science and the Welfare of Mankind}

A Conference on "Science and the Welfare of Mankind" will be held in the Beaver Hall, Garlick Hill, London, E.C.4, during February 15-17. The Conference is being organised by the Association of Scientific Workers in co-operation with the Association of University Teachers, the Institute of Professional Civil Servants and the British Association of Chemists. There will be an introductory session dealing with "Science and World Needs" (chairman, Sir Robert Robinson). The three following sessions will deal with : "The Implications of Recent Scientific Development" (chairman, Sir Richard Gregory) ; "The Responsibilities of Scientists to Modern Society" (chairman, Prof. A. V. Hill) ; "The Organisation of Science" (chairman, Sir Robert Watson-Watt). Among the speakers at the Conference will be $\mathrm{Mr}$. Herbert Morrison, Prof. P. M. S. Blackett, Prof. M. L. Oliphant, Dr. H. L. Richardson, Prof. B. Farrington, Prof. J. D. Bernal, Mr. A. Horner, Dr. Julian Huxley and representative foreign men of science. The Conference will be summed up by Sir Robert Watson-Watt. Tickets for admission (2s. $6 d$. per session, 7s. 6d. for the whole Conference) and further information can be obtained from the Association of Scientific Workers, 15 Half Moon Street, London, W.1.

\section{Summer School on Theoretical Physics in Industry}

A summer school will be held in the H. H. Wills Physical Laboratory in co-operation with the Institute of Physics, during May 30-June 6. The subjects to be studied will cover the general field of conduction of electricity in non-metals and will include luminescence, dielectric phenomena and reactions in solids. The course is intended mainly for members of the research staffs of Government and industrial laboratories who are engaged on experimental research in these subjects. Further particulars may be obtained from the Director of the Department of Adult Education, University, Bristol, 8.

\section{German Aeronautical Developments}

WHEN an exhibition of German aircraft was held last autumn at the Royal Aircraft Establishment, Farmborough, the Minister of Aircraft Production, Mr. John Wilmot, was convinced that the display should also be made available to the general public as soon as possible, at a central site. As a result, an exhibition of German aeronautical developments will be held under the auspices of the Ministry of Education at the Science Museum, South Kensington, commeneing February 14. The exhibition will be open on weekdays from 10 a.m. to 6 p.m., and Sundays from 2.30 p.m. to 6 p.m. for three months. The exhibits are selected from those shown at Farnborough. They comprise a number of typical German military aircraft, including a jet-propelled fighter, flying bomb, the gyro-kite for use with U-boats, a piloted V1, a V2-rocket and radio-controlled rocket weapons. The exhibition coincides with the post-war reopening of the Science Museum for, in addition, the museum also has a series of exhibitions relating to atomic energy, X-rays and the quartz crystal clock.

\section{Announcements}

Dr. J. S. Mrrchell, of St. John's College, Cambridge, has been appointed to the newly established chair of radiotherapeutics in the University of Cambridge.

According to The Times correspondent, the University of Berlin was formally reopened on January 29. All arrangements for the reopening, the appointment of staff, and examining the political antecedents of students were made under Russian supervision. There are about three thousand students in all, and there is a teaching staff of a hundred professors and about a hundred and fifty lecturers.

Elections to three Beit Fellowships for Scientific Research will take place on or about July 6. Candidates must be of European descent by both parents and hold a degree or equivalent qualifications of a university of the British Empire. The age limit is twenty-five. Forms of application (returnable before April 6) and all information may be obtained, by letter only, addressed to the Registrar, Imperial College, South Kensington, London, S.W.7.

The Staveley Coal and Iron Co., Ltd., is establishing a Central Research Department, which will include the research activities of its subsidiary com. pany, Bradley and Foster, Ltd., of Darlaston, in order to co-ordinate all its chemical and metallurgical research. The new Department will be located at Staveley Works, near Chesterfield, and will be known as the Staveley/Bradley Foster Research Department. Its principal object will be the intensification of research and development in all aspects of the manufacture of chemicals and iron and their utilization. Dr. J. H. Hurst, technical director of Bradley and Foster, Ltd., has been appointed director of research to the Staveley Co., and the new Department will be under his direction.

WE have received a pamphlet entitled "50 Years of Scientific Instrument Manufacture" from the Cambridge Instrument Co., Ltd., this being a reprint of an article in Engineering during May and June 1945. The book of twenty-six pages is fully illustrated and gives an interesting story of the development of this well-known firm since its foundation in 1895 by A. G. Dew-Smith and Horace Darwin, the various instruments for which it has become famous being described. There can be no doubt that the company has materially assisted research and the scientific control of industry by its products. Copies of the pamphlet can be obtained from the Publicity Department, Cambridge Instrument Co., Ltd., 13 Grosvenor Place, London, S.W.1. 